\title{
Kennis, macht en overmacht : de lerende organisatie, in het bijzonder de sociocratische kringorganisatie
}

Citation for published version (APA):

Endenburg, G. (1998). Kennis, macht en overmacht : de lerende organisatie, in het bijzonder de sociocratische kringorganisatie. Eburon. https://doi.org/10.26481/spe.19981113ge

Document status and date:

Published: $13 / 11 / 1998$

DOI:

10.26481/spe.19981113ge

Document Version:

Publisher's PDF, also known as Version of record

\section{Please check the document version of this publication:}

- A submitted manuscript is the version of the article upon submission and before peer-review. There can be important differences between the submitted version and the official published version of record.

People interested in the research are advised to contact the author for the final version of the publication, or visit the DOI to the publisher's website.

- The final author version and the galley proof are versions of the publication after peer review.

- The final published version features the final layout of the paper including the volume, issue and page numbers.

Link to publication

\footnotetext{
General rights rights.

- You may freely distribute the URL identifying the publication in the public portal. please follow below link for the End User Agreement:

www.umlib.nl/taverne-license

Take down policy

If you believe that this document breaches copyright please contact us at:

repository@maastrichtuniversity.nl

providing details and we will investigate your claim.
}

Copyright and moral rights for the publications made accessible in the public portal are retained by the authors and/or other copyright owners and it is a condition of accessing publications that users recognise and abide by the legal requirements associated with these

- Users may download and print one copy of any publication from the public portal for the purpose of private study or research.

- You may not further distribute the material or use it for any profit-making activity or commercial gain

If the publication is distributed under the terms of Article $25 \mathrm{fa}$ of the Dutch Copyright Act, indicated by the "Taverne" license above, 


\section{KENNIS, MACHT EN OVERMACHT}


. 


\title{
KENNIS, MACHT EN OVERMACHT
}

\author{
De lerende organisatie, \\ in het bijzonder de sociocratische kringorganisatie
}

Rede gedeeltelijk uitgesproken bij de aanvaarding van het ambt van bijzonder hoogleraar in de lerende organisatie, in het bijzonder de sociocratische kringorganisatie vanwege de Stichting Sociocratisch Centrum aan de faculteit der

Economische Wetenschappen en Bedrijfskunde van de Universiteit Maastricht, op 13 november 1998 door dr ing. Gerard Endenburg.

Eburon

1998 
Uitgeverij Eburon

Postbus 2867

$2601 \mathrm{CW}$ Delft

eburon@info.nl

(C) 1998 G. Endenburg

Niets uit deze uitgave mag worden wermenigvuldigd en/of openbaar gemaakt door middel van druk, fotokopie, microfilm, of op welke andere wijze dan ook, zonder voorafgaande toestemming van de rechthebbende.

ISBN 9051666675

NUGI 661 


\section{Inhoud}

Inleiding 7

Produceren van sociale veiligheid 11

$\begin{array}{ll}\text { De leerweg voor het lerende individu } & 25\end{array}$

De leerweg voor de lerende kring 33

De leerweg voor de lerende kringorganisatie $\quad 40$

Relateren van scholende en lerende kringorganisaties 41

Betekenis voor Universiteit Maastricht 42 
The cost of education is nothing compared to the price of ignorance 


\section{KENNIS, MACHT EN OVERMACHT}

De lerende organisatie, in het bijzonder de sociocratische kringorganisatie

Mijnheer de Rector Magnificus, Geachte dames en heren.

Inleiding

Kennis en macht zijn begrippen die onafhankelijk vanen in relatie tot elkaar ons leven en samenleven zowel in positieve als negatieve zin beïnvloeden. De onderzoeker die op zoek is naar kennis om tot nieuwe inzichten te komen of de bestuurder die macht verwerft voor het beter kunnen leiden van zijn organisatie, kan daarmee zowel een positieve als een negatieve invloed op de samenleving uitoefenen. Het adagium 'kennis is macht' legt een relatie tussen de twee begrippen en duidt daarmee op een situatie, die zowel positieve als negatieve aspecten heeft.

Tegen de aspecten, die als positief worden ervaren zal niemand bezwaar hebben, maar zodra macht verandert in overmacht, kan dat voor ons leven en samenleven dramatische gevolgen hebben. De geschiedenis geeft daar vele voorbeelden van.

Het verwerven van kennis om een overmachtspositie te verkrijgen of het liquideren van aanwezige kennis om de overmachtspositie te behouden zijn be- 
kende werkwijzen in de strijd om een overmachtspositie.

Bij de economische competitie neemt ontwikkeling van bijvoorbeeld nieuwe technologie een sleutelpositie in.

Voor die ontwikkeling is kennis nodig. Dat wil zeggen, ten behoeve van de economische competitie is het laten ontstaan van nieuwe kennis en het verwerven en leren van bestaande van existentieel belang.

In de huidige politiek-maatschappelijke structuur van onze samenleving is het streven naar overmacht, het dwingen tot een win-verlies situatie, tot grote perfectie opgevoerd. Creativiteit, nodig voor ontwikkeling, staat in deze structuur onder grote druk.

Voor de ontwikkeling van nieuwe technologie ondervindt creativiteit weinig tegenstand. Maar voor ontwikkelingen, waar eventueel overmacht aan kan worden ontleend, wordt creativiteit vooral door personen en groeperingen in een overmachtspositie met argwaan bekeken.

Creativiteit kan aldus voor de bestaande machtsverhoudingen een bedreiging vormen. Ontwikkeling en leren bevinden zich in dit spanningsveld. Enerzijds groeit de behoefte aan meer kennis en vaardigheden om de competitie aan te kunnen als ook om de kwaliteit van ons leven en samenleven te kunnen verbeteren. Anderzijds dreigen mogelijkheden van overmacht om juist creativiteit voor ontwikkeling van kennis en vaardigheden tegen te gaan. De economische noodzaak om de competitie aan te kunnen, en beter aan te kunnen dan voorheen, benadrukt de vraag hoe het negatieve aspect van macht, namelijk het overmachtsaspect, te kunnen corrigeren of elimineren en zo optimal de mogelijkheid te creëren woor ontwikkeling van kennis en vaardigheden. 
De nadruk leggen op thet begrip overmacht is voor mij van belang, ondat het begrip ontkenning daaraan is gerelateerd en ontkenning de ultieme vorm van geweld vormt. Macht en overmacht hebben dus direct te maken met 'veilig' en 'onveilig", niet alleen in de zin van Arbo-wet en arbeidsomstandigheden, maar vooral in sociale zin, leven en samenleven.

De vraag is dan hoe een sociaal veilige situatie kan worden gescliapen opdat ontwikkeling en het leren van kennis en vaardigheden optimaal kunnen plaatsvinden. En dat zodanig, dat de positieve kwaliteiten van macht en kennis optimaal tot hun recht kunnen komen en de negatieve, de mogelijkheden van ontkenning, geelimineerd of bestuurbaar kunnen worden. Zoals gezegd, beïnvloedt de positieve en negatieve kant van de relatie tussen kennis en macht onze gehele samenleving. Het beinvloedt bijvoorbeeld het universitair onderwijs, maar ook andere sectoren en ontwikkelingen, zoals in het bedrijfsleven. Maar ook het levenslang leren, waarvan de noodzaak nu algemeen wordt erkend, wordt daardoor beinvloed.

De effectiviteit van het onderwijs staat allang ter discussie en de invloed daarop van het negatieve kennis-macht aspect kan wel eens veel groter zijn dan we ons tot nu toe bewust waren.

Een op deze universiteit toegepaste vernieuwing van het onderwijs, namelijk het probleemgestuurd onderwijs ( $P G O)$, heeft in eerste instantie een positief effect op het studiegedrag van studenten gehad, met name wat betreft het activeren van leerprocessen en leervermogens. Het machtsvraagstuk is daarbij in de oorspronkelijke formulering van PGO zeker erkend, maar is slechts gedeeltelijk opgelost door de docenttutor in plaats van de traditionele leidinggevende rol 
veeleer de rol van facilitator en gids te laten vervullen.

De praktijk van $\mathrm{PGO}$ in bijvoorbeeld de Faculteit der Economische Wetenschappen en Bedrijfskunde laat zien dat deze rol voor veel docenten erg moeilijk is. ${ }^{2}$ Dit leidt tot een onvermijdelijke (gedeeltelijke) terugval van de $\mathrm{PGO}$-praktijk naar traditionele onderwijsvormen, gekenmerkt door overmacht van de docent, waardoor het negatieve kennis-macht aspect niet kan worden geêlimineerd.

Leeropdracht

Ik ben daarom blij met de leeropdracht van deze leerstoel waarin beide aspecten, dat wil zeggen het leren en de sociale veiligheid, aan elkaar zijn gerelateerd. De formulering van de leeropdracht als, 'de lerende organisatie, in het bijzonder de sociocratische kringorganisatie, belooft echter meer dan die twee aspecten.

Wat zit er nog meer verborgen in het begrip 'lerende organisatie' dan alleen het begrip leren en wat omvat het begrip 'sociocratische kringorganisatie' meer dan het begrip sociale veiligheid en waarom zijn ze voor elkaar van belang. Hierover wil ik in deze rede enkele punten aangeven.

Iie bijvoorbeeld: Barrows, H.S. en R.M. Tamblyn, Problem-based learning, New York: Springer, 1980; Moust, J.H.C., De effectieve tutor: meer dan alleen een vakinhoudelijk deskundige?, Tijdschrift voor Hoger Onderwijs, $12(1994)$, p. $95-115$

Gijselaers, W.H., Connecting problem-based practices with educational theory, in: L. Wilkerson \& W.H. Gijselaers (eds.), Bringing problem-based learning to higher education, San Francisco: Jossey-Bass, p. 12-21. Romme, A.G.L., Naar samenwerkend leren in het universitair onderwijs, Tijdschrift voor Hoger Onderwijs, 16 (1998), p. 100-116. 
Ten eerste wil ik iets zeggen over de sociocratische kringorganisatie en hoe daarmee sociale veiligheid, onder meer in de vorm van gelijkwaardigheid bij de besluitvorming, kan worden geproduceerd. Vervolgens hoe de structuur van een lerende organisatie zou kunnen zijn, wat een lerende organisatie is en welke bijdrage de sociocratische kringorganisatie daar aan kan leveren.

Produceren van sociale

Voor hen, die onbekend zijn met het begrip 'sociocratische kringorganisatie' volgt hier een veiligheid beknopte uiteenzetting. ${ }^{3}$ 'Sociocratisch" verwijst naar de daarbij behorende wijze van besluitvorming en het begrip 'kringorganisatie' naar de plek waar die wordt toegepast.

Gesteld dat in een chaotische toestand de 'besluitvorming' wordt geregeerd door wat wij als toeval ervaren en dat in religieus perspectief De Ander of Het Andere regeert dan kan men stellen dat in een autocratie een enkeling of minderheid, in een democratie de meerderheid en bij het toepassen van de sociocratische methode het argument regeert.

Voor die onderscheiden wijzen van besluitvorming gelden de volgende beginselen:

* sociocratie het consentbeginsel.

De overmacht aan het argument dat individu en gemeenschap (met mogelijke inclusie van 'de buitenwacht') op elkaar betrekt.

* democratie het meerderheidsbeginsel.

"Endenburg, G., Sociocratie, als sociaal ontwerp in theorie en praktijk, Delft: Eburon, 1997. 
De overmacht aan het grotere aantal, de omvattender representatie, de meeste aandelen, etc.

* autocratie de enkeling of kleine selecte groep als beginsel.

De overmacht aan de Leider, de

Meerdere, de aristocratische kaste of de expert.

* religie het alles verbindend geloofs- of eenheidsbeginsel.

De overmacht gedelegeerd aan 'het': het alomvattend kristallisatiepunt in jezelf, in de Ander, dan wel in het Andere.

* chaos een opdoemen van niet direct samenhangende mogelijkheden.

De overmacht aan niet samenhangende machtsfenomenen of presentie-mogelijkheden.

Al deze wijzen van besluitvorming hebben positieve en negatieve kwaliteiten.

Alleen vanuit chaos zijn creatieve processen mogelijk, wordt probleemoplossing gecreëerd, start de pionier.

Door in de ander en het andere te kunnen geloven is de mogelijkheid van samendoen, van delegeren mogelijk, we kunnen het immers niet alleen.

Het zelfstandig kunnen beslissen is noodzakelijk om plannen te kunnen realiseren, processen te kunnen leiden.

De meerderheidsbesluitvorming geeft aan iedereen de mogelijkheid mee te beslissen. Binnen sociocratische organisaties is tot nu toe deze wijze van besluiten niet toegepast. 
Toepassing van het consentbeginsel garandeert de mogelijkheid van onderlinge gelijkwaardigheid van allen die aan het besluitvormingsproces deelnemen.

Een negatieve kwaliteit van al deze wijzen van besluitvorming, met uitzondering van de sociocratische, is dat het een mogelijkheid van ontkenning van het individu inhoudt. Wanneer het toeval, 'de ander' of 'het andere', dan wel de baas of de meerderheid de besluitvorming regeert, bestaat de mogelijkheid het individu te ontkennen. Het individu heeft in die gevallen formeel geen mogelijkheid dat te corrigeren.

Wanneer zich ontkenning in een sociocratische organisatie dreigt voor te doen is het juist de kracht van de methode die te kunnen corrigeren dan wel te voorkomen. Niets en niemand accepteert het te worden ontkend en ervaart dat uiteindelijk als geweld. Als reactie daarop kan defensief gedrag ontstaan of kan het agressie oproepen. In de traditionele machtsverhouding tussen boven- en ondergeschikte is defensief gedrag goed waar te nemen. Bij het onderwijs leidt de formele machtsstructuur tot ongelijkwaardigheid tussen meerdere en mindere, tussen docent en leerling. Ondanks pogingen het machtsverschil te vermijden blijft defensief gedrag bij studenten zeer begrijpelijk. In een sociocratische organisatie regeert het consent (dat wil zeggen: het principe van geen bezwaar) als wijze van besluitvorming. Zoals gezegd, wanneer zich daar ontkenning dreigt voor te doen, kan de betrokken groep of het individu dat corrigeren dan wel voorkomen.

Het geven van consent aan een voorstel betekent in zijn meest precieze formulering: het geen overwegend en beargumenteerd bezwaar hebben tegen dat voorstel. Wanneer dus alle betrokkenen consent geven dan is er tot aanname van het voorstel besloten. Wordt er niet door alle betrokkenen consent gegeven dan is er 
besloten het voorstel niet aan te nemen. Voorwaarde is dat het bezwaar tegen het voorstel wordt beargumenteerd en dat het een overwegend bezwaar is. Degene die, met argumenten, geen consent geeft aan een voorstel, is degene die bepaalt of de argumenten overwegend zijn.

Regeren van de besluitvorming wil zeggen dat andere wijzen van besluitworming mogelijk zijn mits daartoe met consent is besloten. Op deze wijze is het bijvoorbeeld mogelijk een beslissingsdomein an iemand te delegeren. Daarbinnen mag die persoon zelfstandig beslissen. Om te voorkomen dat ieder over alles gaat meepraten en beshissen wordt de sociocratische organisatie opgebouwd uit kringen, dat wil zeggen semi-autonome eenheden die ter realisatie van de eigen doelstelling zelfstandig mogen beslissen.

Van wezenlijk belang daarbij is om een onderscheid te maken tussen beleidsbepalende en beleidsuitvoerende besluitvorming. Dat wil zeggen: binnen de kringen wordt met consent het beleid bepaald dat vervolgens in de uitwoerende organisatie wordt gerealiseerd. Zie daarvoor figuur 1.

Figuur 1.

Leidinggevende- en Kringorganisatie

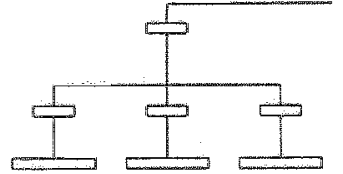

Beleidsuitudering

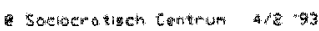

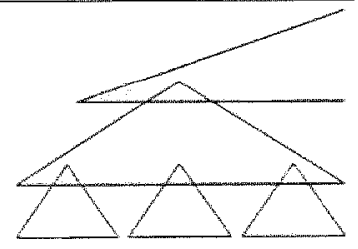

Eeleidsbepuling

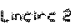


Voor de realisatie van het in de kringen bepaalde beleid in de uitvoerende organisatie worden in de kringorganisatie beslissingsdomeinen aan de kringleden gedelegeerd, waarbinnen zij, zoals hiervoor betoogd, zelfstandig mogen beslissen.

Op deze wijze is het binnen de kringorganisatie mogelijk bijzonder effectief te vergaderen opdat de creativiteit optimaal tot zijn recht kan komen.

Immers binnen de kringen worden alleen beleidsbesluiten genomen en in de uitvoerende organisatie alle uitvoerende besluiten. Ieder kringlid, ongeacht status of functie, heeft het consentrecht en kan daarmee als uniek individu gelijkwaardig aan de besluitworming deelnemen. Het samenstel van kringen, de kringorganisatie, vormt een afspiegeling van de structuur van de uitvoerende organisatie. De kringen van de kringorganisatie vormen de plekken waar met consent beleid wordt bepaald, structuur wordt geproduceerd en de nodige functies en taken worden toegedeeld. Een kring is de plaats voor chaos, voor optimale creativiteit, waar het delegeren van functies en taken het onderling vertrouwen aangeeft, in hoeverre de kringleden elkaar geloven en wat de domeinen voor zelfstandige besluitvorming zijn.

Het doel van de sociocratische kringorganisatie is dat ieder die deel uitmaakt van een organisatie op voet van onderlinge gelijkwaardigheid, met consent, kan deelnemen aan de besluitvorming.

Het is een methode om organisatie te produceren en te leiden op basis van de hiervoor genoemde gelijkwaardigheid met consent.

Consent en Beslissen met consent wijkt principieel af van consensus besluitvorming middels consensus. Het vraagt niet om een onvoorwaardelijk 'ja' zoals bij consensus, maar 
geeft de mogelijkheid van een 'beargumenteerd en overwegend nee'.

Binnen met consent geconstitueerde grenzen ontstaat zo nodig rumte woor chaotische, religieuze, autoritaire, democratische en - uiteraard - sociocratische besluitvorming. Ook mengvormen, zoals besluitvorming volgens consensus, laten zich aldus bestuurlijk demarkeren.

Consent en consensus verschillen van elkaar zoals een pluralistische gemeenschap verschilt van een solidaire eenheid. Het consentbeginsel geeft de mogelijkheid om in chaos door demarkeren tot de helderheid te komen van een beleidsvoering die mensen en hun omstandigheden niet overweldigt, maar wel een weerstandsvermogen tot ontwikkeling brengt tegen mogelijk onverhoeds opkomen van willekeur bij machthebbers en systeemdwang bij blokvormende meerderheden.

De sociocratische methode gaat uit van vier basisregels.

Consentbeginsel:

Het consentbeginsel, dat wil zeggen: de afspraak, dat het beginsel van geen bezwaar de besluitvorming regeert.

Kringorganisatie:

Het beginsel van de kringorganisatie, dat wil zeggem: de afspraak dat een organisatie wordt opgebouwd met behulp wan kringen.

Elke kring heeft een eigen doelstelling, vervult de drie functies: 
leiden, uitvoeren en meten/terugkoppelen en onderhoudt zijn eigen geheugensystemen door middel van integrale scholing.

\section{Dubbele koppeling:}

Het beginsel van de dubbele koppeling, dat wil zeggen: de afspraak, dat bij de verbinding tussen twee kringen minstens twee personen uit de ene kring deelnemen aan de besluitvorming in de naast hogere kring, te weten: de functionele leider en de gekozen afgevaardigde( $(n)$.

Kiezen van personen:

De afspraak, dat het verkiezen van personen uitsluitend gebeurt mer consent, na een open discussie.

Dit beginsel heeft de status van een toegevoegde procedure-regel.

Het regeren van de besluitvorming door het consentbeginsel wil zeggen, dat tot de aanname van een beleidsvoorstel is besloten wanneer niemand van de kringleden daar een beargumenteerd en overwegend bezwaar tegen heeft. Indien iemand wel een zodanig bezwaar heeft is er geen consent en is besloten het voorstel niet aan te nemen.

Regeren van de besluitvorming wil (ook) zeggen: met consent kan worden besloten een andere wijze van besluitvorming toe te passen. Bijvoorbeeld aan iemand met consent een beslissingsdomein delegeren waarbinnen die persoon zelfstandig mag beslissen.

Een sociocratische kring heeft veel overeenkomst met een semi-autonome groep. Beleidsbesluiten worden altijd in een kring genomen. 
Basis van

sociale

veiligheid

Produceren van dynamische organisatie
Met het toepassen van de sociocratische methode hebben we aan een belangrijke voorwaarde voldaan om naar een oplossing voor de kennis-machtproblematiek te kunnen zoeken, te weten een methode die de vereiste sociale veiligheid produceent.

Op deze basis van veiligheid kunnen we dan onze organisaties construeren. Hoe dat te doen is dan een volgende vraag.

Wanneer we het er over eens zijn dat leven en samenleven het karakter heeft van een samenstel van dynamische processen, is de vraag wat we daaronder verstaan, hoe we die processen kunnen produceren en vervolgens leiden.

Onder een dynamisch proces versta ik een proces dat mogelijk is dankzij factoren die veranderlijk zijn, meestal onwoorspelbaar veranderlijk. Gesteld dus dat leven en samenleven een samenstel van dynamische processen is, dan volgt daaruit dat het veranderlijk, meestal onvoorspelbaar veranderlijk is, dat wil zeggen instabiel.

Het leiden van zulke processen is derhallve noodzakelijk, evenals het kunnen corrigeren daarvan. Die noodzaak is structureel om tot die bewuste processen te komen. De structuren waarin die instabiele processen zich voltrekken moet het mogelijk maken die te besturen en te corrigeren. De vraag hoe die structuren er uit moeten zien, de vormgeving, leidt ons naar de cybemetica. De cybernetica geeft ons enige informatie daarover.

De vormgeving van structuren voor dynamische processen in de technologie werd pas goed mogelijk na toepassing van de regels uit de cybemetica. Het toepassen daarvan op onze sociale structuren die moeten leiden tot de gewenste sociale processen ondervindt grote vertraging. De kennis daarover is be- 
perkt en de weerstand tegen de ontwikkeling daarvan is groot. Die weerstand is weliswaar te verklaren uit een begrijpelijke vrees voor nieuwe vormen van overmacht, maar ook opmerkelijk. Want wanneer we ervan uitgaan dat een situatie het gevolg is van een proces en dat proces een gevolg van structuur, inclusief de actoren, dan kan die situatie worden verbeterd of veranderd door een andere vormgeving van de structuur.

Kennis over vormgeven en in dit verband vormgeven wan sociale strwcturen zou dan ook zo snel mogelijk moeten worden ontwikkeld en geleerd. Daarbij komt als extra moeilijkheid, dat de formele sociale structuur, die van zichzelf dynamisch is, de informele of beter de impliciete, inclusieve structum dient te faciliteren.

Die inclusieve structuur ontstaat intuittief en gevoelsmatig en is dermate complex dat die niet te expliciteren is. Intuittie en gevoel zijn waarschijnlijk de resultanten en de bron van die complexiteit en voor ons de enige informatie voor het organiseren van ons leven en samenleven. De formele structuur dient dat proces te faciliteren.

Ondanks het feit dat kennis over het vormgeven van onze sociale structuren beperkt is heerst hier welvaart. Kennelijk doen we veel zaken op een goede manier. Nu echter de kwaliteitseis ons stuwt naar beter, wat we daar ook onder verstaan, groeit de noodzaak om te weten hoe we de formele structuur moeten vormgeven opdat die de impliciete, inclusieve beter faciliteert. Ontwikkelen en leren van die kennis en vaardigheden is in toenemende mate van belang en gezien de dreiging van het overmachtsaspect is sociale veiligheid daartoe noodzakelijk. 
Bij de vormgeving van de huidige sociale structuur doet zich nog een moeilijkheid voor en wel bij de projectorganisatie. Elke organisatie kent een proces van doelrealisatie dat is onder te verdelen in processen van subdoelrealisaties enz. Die verschillende soorten processen van doelrealisatie zijn te beschouwen als projecten. Het gaat dan dus om het vormgeven van sociale structuren als projecten.

Produceren van projectorganisatie
Leiden van dynamische organisarie
Het produceren van structuur voor een project is te onderscheiden in constructie, reconstructie en déconstructie daarvan. Reparatie maakt daar ook onderdeel van uit, maar is van een andere orde. In het kort wil dat zeggen: voor een project wordt structuur gemaakt, gebruikt en eventueel hermaakt en afgebroken. Dat afbreken, de déconstructie, is van belang voor de continuïteit van een organisatie. De kennis van projectorganisatie is zich aan het ontwikkelen, maar staat nog in de kinderschoenen.

Bij het vormgeven aan sociale structuren is het van essentieel belang, zoals hiervoor reeds aangegeven, onderscheid te maken tussen beleidsbepaling en beleidsuitvoering. Daartoe voegt de sociocratische methode aan de bestaande uitvoerende organisatie de kringorganisatie toe.

Beleid maken in kringen wil dan zeggen: op elke plek in de organisatie. Voor de 'social engineer' is dat een constructieregel. Al deze aspecten hebben te maken met het creatieve proces van 'social engineering'. Een vak dat gezien het grote belang met spoed zou moeten worden ontwikkeld en geleerd.

Het leiden van de hiervoor genoemde complexe en dynamische processen wijkt af van de gebruikelijke commando-methode. Natuurlijk worden er opdrachten gegeven, maar voor het leiden van deze dynamische 
complexiteit is het een vereiste uit te gaan van cybernetische en daarvan afgeleide sociocratische principes. Voor die wijze van leiden moet de formele kant nadrukkelijk worden ontwikkeld en geleerd en wel zodanig, dat het de intuitieve en gevoelsmatige kant kan ondersteunen. Het leiden op voet van onderlinge gelijkwaardigheid bij de besluitvorming geeft onverwacht positieve mogelijkheden vergeleken bij de traditionele manier, die structureel is gebaseerd op de ontkenningsmethodiek. De cybemetica geeft de leidinggevende de mogelijkheid de dynamica van de processen te sturen en de gelijkwaardigheid bij de besluitvorming geeft de leidinggevende de mogelijkheid het lerende en scholende aspect van die functie tot zijn recht te laten komen.

Omdat de dynamica zich uit in alle onderdelen van een proces , dat wil zeggen: elk deel van een proces is meer of minder instabiel, heeft elke actor een leidinggevende taak en daarmee een lerende en scholende opgave. Immers in een organisatie, waar ieder leidt, wòrdt ook ieder geleid, dus bevindt iedereen zich zowel in een lerende als in een scholęnde omgeving. Dit acht ik een fundamentele vaststelling voor het invullen van mijn leeropdracht.

Produceren van communicatie
Communicatie is voor het succesvol kunnen functioneren van een dynamische organisatie van evident belang. Een open deur misschien, maar mijn ervaring is dat er weliswaar veel geschoold wordt in communicatie, maar dat de kennis van communicatieprocessen ontoereikend is.

Veel kennis over communicatie gaat uit wan de ontkenningsmethodiek. Winnen en verliezen spelen daarbij een grote rol. ledereen wil woorkomen verliezer in het gesprek te worden. Toepassing van de tot nu toe bescheiden kennis over op onderlinge gelijkwaar- 
digheid gebaseerde communicatie levert al verrassende en positieve, ontdekkende resultaten op.

Reeds lang geleden pasten handelaren op allerlei soorten markten het 'zich wederzijds op elkaar betrekken' toe, eén van de belangrijke communicatieprocessen, om tot ruil van hun waren te komen. Zonder te weten waarom besloten zij daarbij met impliciet consent. De ervaring had geleerd dat dit de meest doeltreffende methode was. Zeker nu de complexiteit, abstractie en virtualiteit van de samenleving zo snel toenemen, neemt ook de noodzaak toe te weten wat de kenmerken van de bedoelde wijze van communiceren zijn. Het is noodzakelijk te weten wat communicatie in die bredere zin betekent. Medewerkers van het Sociocratisch Centrum, die zich hiermee bezighouden kwamen onlangs tot de conclusie dat wanneer 'het ik', 'de ander' en 'het andere" gelijkwaardig aan de besluitvorming kunnen deelnemen, dat gevolgen heeft voor de wijze van communiceren. Met als belangrijke toevoeging dat dan voor het materiële, gevoelsmatige, intuïtieve en spirituele een gelijkwaardige plek wordt ingeruimd. Dit vormt een voorbeeld van een expliciete wijze van besluitvorming, die de inclusieve of impliciete faciliteert. Ook daarom is het van belang communicatie verder te ontwikkelen en te leren.

Produceren van lecrweg
Uit wat ik hiervoor betoogde over het produceren van veiligheid, produceren van dynamische structuur, leiden van die dynamica en produceren van communicatie komt steeds de noodzaak tot leren en ontwikkelen natr voren. De overmachtsdreiging, die kan uitgaan van kennis welke in ontkennende zin wordt gebruikt, kan niet alleen aanleiding geven to defensief, maar ook tot agressief gedrag. De ervaring leert echter dat vechtgedrag, ook verbale agressie, tot wederzijdse ontkenning leidt, slechts - tijdelijke - 
winnaars en verliezers oplevert, en witeindelijk niet een betere situatie schept, maar leidt tot wederzijdse verslagenheid. Het belang van deze tijd is dat we dat proces ook theoretisch kunnen onderbouwen.

Maar in de praktijk blijft ons politiek-maatschappelijk functioneren gevangen in een expliciete, in de wet verankerde regelgeving, die structureel tot ontkenning van het individu en andere minderheden leidt.

Die formele structuur staat echter valk op gespan nen woet met de informele, impliciete, inclusieve structuur. Het faciliteert die meestal niet en is er zelfs vaak mee in strijd. Wat betekent die notie voor de structuur van het leren? Wat is de formele structuur en welke de impliciete, inclusieve? En wordt laatstgenoemde door de formele gefaciliteerd?

Gesteld dat de structuur van het leren de leerweg aangeeft dan rijst de vraag hoe die er uit moet zien opdat agressief en defensief gedrag kunnen worden omgezet in leer- en ontwikkelingsactiviteit.

Het is noodzakelijk kennis en vaardigheden te leren en te ontwikkelen, als sociale technologie, die nodig is ten behoeve van èn ons eigen èn ons gezamenlijk functioneren voor:

* het produceren van sociale veiligheid

Door gelijkwaardigheid bij:

- besluitworming

- bestaansmogelijkheid

- ontwikkeling

* het produceren van dynamische organisatie

* het leiden van die dynamica

* het produceren van communicatie

Onder meer door het:

- wederzijds op elkaar betrekken

* het produceren van een leerweg 
Wanneer we het leren, dat wil zeggen het levenslang leren, op elke plek in een organisatie willen vormgegeven, hoe ziet die structuur, die leerweg er dan uit?

On een antwoord op die vragen te vinden kunnen we Hypothese uitgaan wan de al genoemde constructieregel als hypothese: een situatie is altijd procesafhankelijk en een proces wordt bepaald door een structuur en de actoren daarin. Met andere woorden: de sociale structuren waarvan we deel uitmaken zijn in hoge mate bepalend voor de situaties waarin we leven, voor ons handelen.

Deze hypothese heeft op vele terreinen zeer verreikende consequenties. Het valt buiten het kader van deze rede om daar nader op in te gaan. Toch will ik enkele terreinen noemen. Bijvoorbeeld dat wan de werkgelegenheid. De arbeidsmarkt is ò overspannen of leidt tot werkloosheid dan wel, zoals nu, doen beide situaties zich gelijktijdig voor. Meer dan een miljoen mensen die niet aan het arbeidsproces kunnen deetnemen en meer dan honderdvijftigduizend vacatures. Hoe ziet de structuur eruit die dat veroorzaakt? Hoe zou die er uit moeten zien om de arbeidsmarkt te kunnen sturen?

Hetzelfde geldt voor onze economie, die schommelt tussen onder- en oververhitting. De structuur daarvan is mensenwerk. Dus als de situatie ons niet bevalt hebben we die zelf veroorzaakt. In beide gevallen gaat het om een vormgeving- en besturingsvraagstuk. Ernstiger problemen doen zich voor op het terrein van de criminaliteit. Uitgaande van de gestelde Inypothese kunnen we concluderen dat wij zelf criminaliteit produceren als gevolg van de door ons gemakkte structuur, vervolgens de zelf geproduceerde boeven moeten vangen en daarvoor steeds meer 'politie' nodig hebben. 
Sinds 1970 is het in een toenemend aantal sociocratisch functionerende organisaties de ervaring dat $z i j$ geen sancties, geen straf nodig hebben om te kunnen sturen. Uiteraard vindt men ook binnen sociocratisch functionerende organisaties afwijkend gedrag; dat is immers een natuurlijk gegeven, een eigenschap van een dynamisch proces. Maar de organisatie heeft de structurele mogelijkheid dat zelf op de plaats waar het zich voordoet te corrigeren, door middel van het zelfsturend en zelfcorrigerend vermogen van de sociocratische methode.

Tenslotte geldt de hypothese ook voor geweld. Geweld als reactie op ontkenning en overmacht wordt in hoge mate bepaald door de structuur van de organisatie waarin het optreedt. Wanneer we geen geweld willen is de vraag welke structuur daarvoor nodig is en hoe het daaruit volgende proces kan worden bestuurd.

Hiermee zijn we terug bij het begin van dit betoog namelijk geweld als ultieme vorm van ontkenning en de reactie daarop, wetend dat niets en niemand ontkenning accepteert. De natuur accepteert dat evenmin als de - van die natuur deel uitmakende - mens. Ontkennen wij onze natuurlijke omgeving, dan verdwijnt de ozonlaag en sterven de bossen. En, zoals gezegd, de ontkende mens gaat in verzet en vertoont defensief of agressief gedrag.

Wat betekent de gestelde hypothese als constructieregel voor het vinden van antwoorden op de hiervoor gestelde vragen?

Leerweg voor het lerende individu
Uit het voorgaande moge blijken dat leren mòet, en wel levenslang. ledereen, èn als individu èn in samenhang met de groep (c.q. kring) waarvan het deel uitmaakt moet leren, te allen tijde en op elke plek van de samenleving. Tevens zal door het voorgaande 
duidelijk zijn dat om het leren te faciliteren sociale veiligheid noodzakelijk is en de sociocratische kringorganisatie daarvoor als methode kan worden gebruikt.

We keninen de structuur, die binnen ons huidige onderwijsstelsel het leren vorm geeft. We kennen ook de positieve kwaliteit daarvan, namelijk datgene te kumnen leren wat we mogelijkerwijs nodig hebben voor ons bestaan. De negatieve kwaliteit vat ik hier samen in het begrip 'ontkenning'. De leerkracht onderwijst en beoordeelt met als wettelijke bevoegdheid zelf te beslissen in hoeverre de leerling daarbij betrokken mag zijn. Het gevolg ligt voor de hand: studenten ontwikkelen weliswaar vaardigheden in het reproduceren van kennis, maar stellen zich defensief en soms zelfs agressief op.

Zowel de leerkracht als de leerling bevindt zich in dezelfde onderwijsstructuur. Beiden zijn gevangen binnen regels die ontkenning een legale status geven. Vele onderwijsvernieuwers hebben geprobeerd daarin verandering te brengen en menig onderwijsvernieuwend initiatief is tot nu toe getoetst in de praktijk. Bekend zijn onder anderen: Maria Montessori, Peter Petersen (Jenaplan), Rudolf Steiner (Vrije school), Chris Argyris, en initiatieven als de middenschool, het tweefasen onderwijs en het studiehuis. ${ }^{4} \mathrm{Bij}$ al deze vernieuwingen en initiatieven bleef echter de overmachtsstructuur van het onderwijs onveranderd en bleef dus de mogelijkheid tot ontkenning bestaan.

${ }^{4}$ Zie onder meer: Maria Montessori, De methode Montessori, Zwolle: Ploegsma, 1916; Rudolf Steiner, De opvoeding van het kind in het licht der anthroposofie, Utrecht: De Haan, 1923; Chris Argyris, On organizational learning, Cambridge: Blackwell, 1992; Wijnen, W.H.F.W., Studiehuis: een bruikbaar concept voor het onderwijs, Tijdschrift voor Hoger Onderwijs, $15(1997)$, p. $47-54$. 
Voor zover ik weet is Kees Boeke de enige die juist in die structuur vernieuwing aanbracht. Maar onderwijsvernieuwing was niet diens primaire doelstelling. Hij ontwikkelde onderwijs vanuit zijn streven naar maatschappijvernieuwing. Boekes vernieuwing was gebaseerd op Quaker-principes, waarbij het streven naar geweldloosheid een essentiële plaats inneemt. Zijn Werkplaats Kindergemeenschap, zoals hij de school noemde, had als kenmerk de integratie van werken en leren, waarbij hij onder werken alle activiteiten verstond. In hoeverre zijn ideeën realistisch of utopisch waren is in dit verband niet zo interessant; van belang is de gedachte daarachter, dat elk individu, van peuter tot oudere, gelijkwaardig bij de besluitvorming aan het eigen en gezamenlijke leven kan werken en leren. Voor mij zijn dat nog steeds belangrijke uitgangspunten.

De vorm van de machtsstructuur die als basis dient voor ons leren, is bepalend voor de kwaliteit ervan. De vorm, de structuur van die basis, dient de bepleite gelijkwaardigheid bij de besluitvorming mogelijk te maken, daardoor ontkenning te voorkomen en vervolgens open te laten hoe en wat er wordt geleerd.

Alle soorten en wijzen van onderwijs, eventueel afhankelijk van cultuur en religie, kunnen dan worden gepraktiseerd. We spreken daarom van een 'lege' leerstructuur. Dat wil zeggen, een expliciete leerstructuur, die wel inhoud heeft maar geen inhoud voorschrift. De structuur is faciliterend. Wanneer we zulk een lege leerstructuur kunnen produceren, hebben we an het onderwijs een essentieel aspect toegevoegd.

'Boeke, K., Kindergemeenschap: ervaringen en perspectieven van De Werkplaats'te Bilhoven, Utrecht: Bijleveld, 1934. 
Hoe ziet een dergelijke structuur er uit? Welke constructieregels gelden daarvoor en wat is leiden in deze context?

De sociocratische methode voorziet in de structuur en constructieregels, die de onderlinge gelijkwaardigheid bij de besluitvorming garanderen en het produceren en leiden van een organisatie mogelijk maken. Voor het leren geldt ook de 'overlap' als constructieregel. De situatie waarin een individu zich bevindt is bepalend voor het kunnen ingaan van een volgende situatie. De input van een volgende situatie is altijd de output van één of meer vorige situaties. Daarbij kan de volgende situatie voor de betrokken persoon bekend of onbekend zijn. Beide omstandigheden vragen on een bepaalde vorm van 'overlap'. Zonder deze gaat het niet.

Behoefte aan kennis en ervaring, kortom: aan leren, is één van de drijvende krachten achter het menselijk bestaan. Dat will zeggen: het verschil tussen werkelijke en gewenste of nodige situatie stuwen tot actie, tot activiteit. De behoefte aan leren is een wezenlijk aspect van de algemeen geldende behoefte aan verbetering van de bestaande situatie, aan 'beter'. Wat iemand onder 'beter' verstaat moet die iemand zelf weten. Het leven, instabiel als het is, vraagt voortdurend en in eindig doch onbegrensde mate om verbetering. De instabiliteit, die als verstorend kan worden ervaren, vraagt om beter en geeft ook de mogelijkheid tot voortdurende verbetering. Binnen een dynamisch proces kan het altijd beter. Dat eist activiteit. Het gaat niet vanzelf. Dat wil zeggen: ieder individu moet zelf aan het werk om aan de eigen behoeften te kunnen voldoen. 'Zelf werken' betekent in de eerste plaats: aan zichzelf, aan het eigen bestaan leiding geven.

Zelf zal men de daartoe nodige spanning moeten opwekken in grootte en soort en die regelen opdat de 
nodige activiteit ontstaat. Leiden is tot leven wekken. Persoon als organisme. De persoon onderscheiden in subpersoonlijkheden geeft het individu daartoe mogelijkheden. Omdat het aantal, de soort en de omvang van de behoeften van een individu 'eindig doch onbegrensd' zijn, kan niemand in zijn eentje daaraan voldoen. Door middel van 'het zelf", 'de ander' en 'het andere' is het mogelijk zo goed mogelijk aan de bevrediging van de eigen behoeften te werken. Daarin manifesteert zich het economisch motief van ons handelen. Door voor ons zelf èn voor de ander of het andere te werken kan de ander of het andere ook voor ons werken. Er is sprake van ruil.

De omgeving van het individu is dat wat zich aan mogelijkheden voordoet on te ruilen. Laten we ons hier beperken tot de sociale omgeving. In zijn sociale omgeving vindt iemand personen die op een bepaald gebied beter, of even goed, of minder goed zijn dan hijzelf. In al die gevallen ontstaat behoefte aan leren: van "de betere" om beter te kunnen worden, met de "even goede' om eventueel elkaar te kunnen corrigeren en aan de "minder goede" om diens kwaliteit te verbeteren. Al die leerprocessen komen de kwaliteit van de sociale omgeving en dus ook die van de betrokken personen ten goede.

Het patroon van de leerweg van het individu is schematisch weergegeven in figuur 2. De leerweg binnen de leidinggevende organisatie ziet er uit zoals weergegeven in figuur 3 . 
Figuir 2.

Patroon van de leerweg van een individu

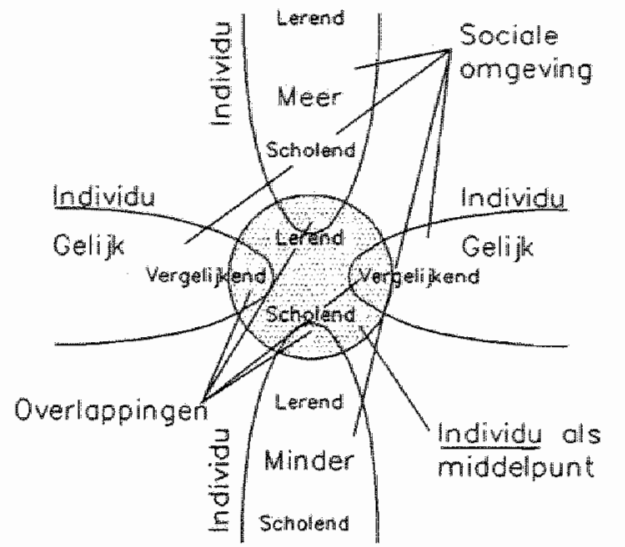

Heser. minder en gelijh oan kennis en/al voordigheder

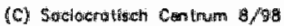

Larage 2

Figuur 3 .

Leerweg van een individu in de leidinggevende org.

Sociale
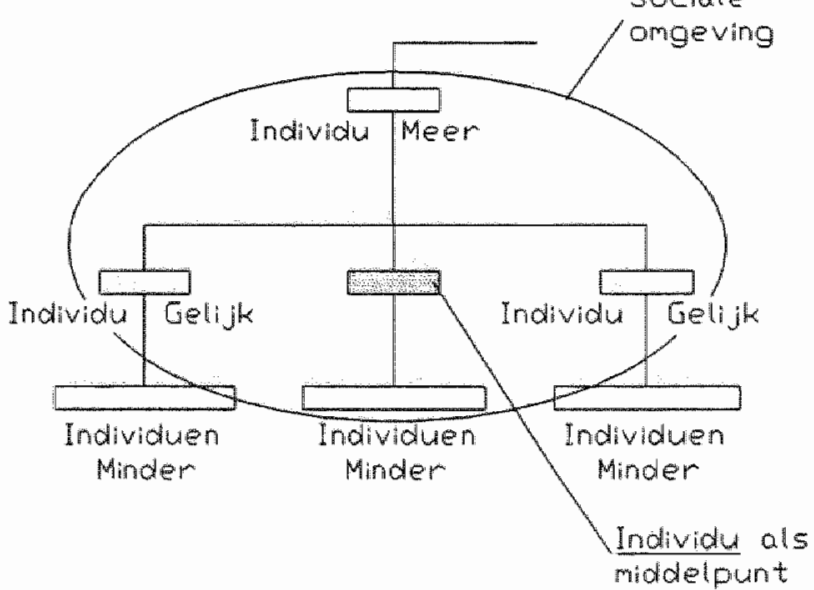

Meer, minder en gelijk aon kennis en/of vaardigheden 
Zoals hiervoor betoogd kunnen we dit patroon als 'leeg' beschouwen. Het heeft inhoud, maar schrijft geen inhoud voor. lemands cultuur en religie bijvoorbeeld en die van zijn sociale omgeving vullen deels dat lege patroon in. De 'zin', die iemand aan zijn bestaan geeft, de richting van zijn persoonlijke ontwikkeling vormt ook een invulling en zal een overlap nodig hebben met de 'zin' van zijn sociale ongeving. Het patroon staat voor de sociale omgeving in alle richtingen open. Het geeft aan het individu een richting voor het eigen ontwikkelingsproces. Iemand kan actief bezig zijn met het verleden van zijn ontwikkeling, met het heden en met de toekomst daarvan door zich daar wederzijds op te betrekken. Dit patroon geeft de persoon een formele basis voor eigen ontwikkeling door leren, vergelijken en scholen, waarmee het impliciete proces wordt gefaciliteerd. Het patroon vormt de leerweg die daarmee het impliciete leerproces faciliteert. Op deze wijze is de leerweg een leeg traject dat structureel in nauwe relatie staat tot de ' $z$ in', die het individu aan het bestaan geeft.

De in het patroon aangegeven overlappingen zijn de gebieden die het individu gemeenschappelijk heeft met verleden, heden en toekomst van zijn ontwikkeling. Hieruit volgt, dat wat geleerd moet worden uitgaat van dat wat wederzijds, onderwijzende en lerende, bekend is naar dat wat voor het lerende individu nog onbekend is.

In het patroon van het leerproces is een drieslag te herkennen die vroeger werd geduid als meester, gezel, leerling. Die termen zijn nu ook te gebruiken, mits in gedynamiseerde vorm en sociocratisch, dat wil zeggen: bij het bepalen van beleid gelijkwaardig aan de andere deelnemers aan het leerproces.

Het is de gezel, het lerende individu over wie we steeds spreken. Zie daarvoor figuur 4 . 
Figur 4.

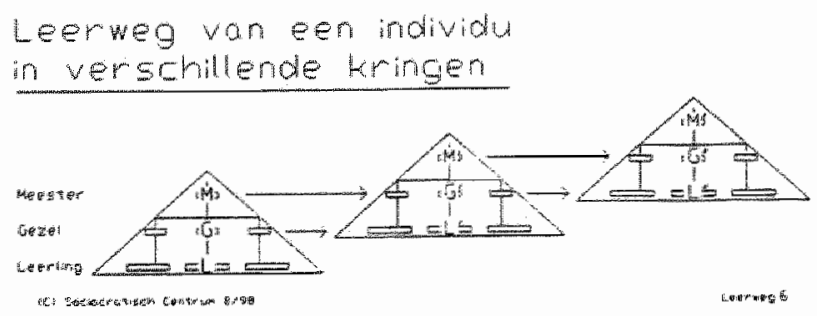

Onder leerweg kan ook worden verstaan een volgorde van te leren materiaal in modulevorm, dat wil zeggen: leermiddelen, verdeeld in logisch op elkaar aansluitende blokken.

Maar hier wordt onder leerweg verstaan: een relatiepatroon in een sociale context. Het patroon van de leerweg geldt voor iedereen. Ieder individu leert levenslang en kan zich ontwikkelen door gebruikmaking van dat patroon. In het patroon van de leerweg, opgebouwd uit drie fasen, is ook een leidinggevende hiërarchie te zien. Het individu als middelpunt wordt geleid bij het eigen leerproces en geeft zelf leiding aan het leerproces van een ander. Het geleid worden en het leiding geven gebeurt beide ten eigen bate.

In sociocratisch perspectief hebben beiden, leidinggevende en geleide, consent aan die situatie gegeven. Het geeft op die manier mogelijkheden voor een bepaalde wijze van leiden en geleid worden. Hiervoor heb ik reeds aangegeven wat het leiden op die manier inhoudt, ofwel wat het leiden van dynamische processen op basis van gelijkwaardigheid bij de besluitvorming inhoudt.

Het individu kan, gebruikmakend van het hiervoor getekende patroon, het eigen leertraject vormgeven, 
samen met de context waarin hij of zij zich bevindt en gebruikmakend van de sociocratische krügorganisatie, dat wil zeggen op basis van gelijkwaardigheid bij de besluitvorming met de actoren uit zijn sociale ongeving.

Uiteraard geldt dit ook voot de betrokken sociale omgeving. Het is een wederzijds op elkaar betrekken. Sterker nog: vanuit de sociale omgeving kunnen initiatieven worden ontwikkeld on bijvoorbeeld individuen te stimuleren tot leren en daarvoor bepaalde leerwegen te initiëren.

Leerbehoeften manifesteren zich niet alleen bij de lerende. Ze worden zowel opgeroepen bij de lerende, die zelf kennis en vaardigheden wil opdoen, alsook bij de scholende, die wil dat de ander kennis en vardigheden opdoet, beiden ten bate van zichzelf. Maar ook ontstaan er behoeften bij de lerende die wil dat de scholende hem helpen kan met het verwerven van kennis en vaardigheden. Zie daarvoor figuur 5 .

Het zich 'wederzijds op elkaar betrekken' is onvermijdelijk, willen scholenden en lerenden uit wederzijds belang samen werken aan het realiseren van hun gemeenschappelijke doelstelling.

Op grond hiervan lijkt de vraag gerechnaardigd of in de traditionele onderwijssituarie sprake is van een gemeenschappelijk belang, een wederzijdse afhankelijkheid, van lerenden en scholenden.

Leerweg voor de lerende kring
Doordat iedereen zèlf aan het voldoen van eigen behoeften kan en dient te werken, is een individuele leerweg noodzakelijk. Dat scholingsproces zal dan op de zojuist beschreven wijze moeten worden georganiseerd. Hetzelfde geldt voor groepen ofwel functionele eenheden. In dat geval ontstaan samenwerkingsverbanden om met elkaar dat te produceren, waaraan andere groepen of enkelingen behoefte hebben. Geza- 
menlijk produceren maakt het mogelijk kwalitatief beter te voldoen aan meer en omvangrijker behoeften. Is men op die manier samen bezig, dan wordt het mogelijk ook samen aan een samenstel van ieders behoeften te werken, samen de doelstellingen daartoe op elkaar af te stemmen, die vast te stellen en samen de daarvoor nodige functies te verdelen. Een analogie wan wat ik betoogde over het individu geldt voor een groep. De groep heeft een eigen doelstelling waarin de eigen behoefte is geformuleerd.

Figuru 5.

Wederzijdse afhankelijkheid van scholende en lerende

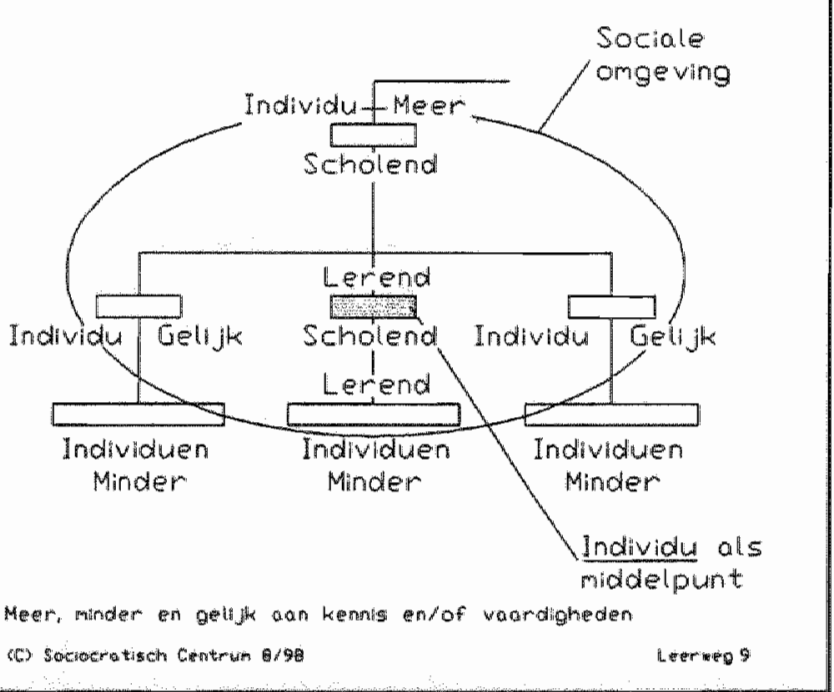


Het proces van doelrealisatie vraagt om een structuur van functies en taken, die door leden van de groep worden uitgeoefend. De functies en taken zijn zodanig geformuleerd, dat zij als subdoelstellingen of subbehoeften zijn te omschrijven. De structuur vormt het formele samenstel van behoeften met hun overlappingen. leder lid van de groep vervult éen of meer functies en taken en heeft dus te voldoen aan één of meer behoeften, die samen met de andere behoeften in de groep de gezamenlijke behoefte vormen.

Analoog aan het individu heeft de groep een eigen geheugensysteem om met behulp daarvan het realiseren van de eigen doelstelling of het voldoen aan de eigen behoeften mogelijk te maken. Het geheugensysteem van de groep wordt opgebouwd door de geheugens van de afzonderlijke groepsleden. Zo kan de groep aan het realiseren van de eigen doelstelling werken. Dat betekent onder meer zichzelf kunnen leiden, zelf de nodige spanning kunnen oproepen en regelen, opdat de nodige activiteit ontstaat. Leiden is letterlijk: de groep tot leven wekken en vervolgens levend houden. De groep krijgt dan het karakter van een organisme. Zij, kan haar eigen synergie opwekken en (ondergaat haar eigen) entropie.

Binnen de sociocratie krijgt een groep, die overgaat van organisatie naar organisme, de naam ' $\mathrm{kring}$ ' (zie de tweede basisregel). Het woord kring verwijst naar het cybernetische kringproces. Er bestaan meer analogieën tussen individu en kring. Zo heeft ook de kring een 'zin'. Over het algemeen wordt die uitgedrukt in de begrippentrits 'visie, missie, doelstelling'. Een kring heeft andere kringen nodig om aan de verwezenlijking van de eigen doelstelling te kunnen werken. Met die andere kringen moet de kring dan overlappingen hebben. Die vormen de sociale omgeving voor de betrokken kring. 
Beleidsbepaling en scholingsbehoeften
De kring is open zowel in bestuurlijke zin (zie de derde basisregel, de dubbele koppeling) als in producerende zin. Bij het laatste komt het economische motief naar voren in de vorm van ruil, (een tweevoudige dubbele koppeling).

Analoog aan het individu heeft de kring leerbehoeften. De vraag is hoe het organisme (de kring), als samenstel van organismen (de individuele kringleden), kan leren. Dat te doen in analogie met het leren van het individu, roept nieuwe vormgevingsvragen op.

Het hiervoor bepleite onderscheid tussen beleidsbepaling en beleidsuitvoering geeft een handvat. De scholingsbehoeften die bij de beleidsbepaling in de kring ontstaan hebben een ander karakter dan die bij de beleidsuitvoering.

De kring is de plek, het orgaan, waar de deelnemers daarvan, ter realisatie van de kringdoelstelling, met consent het belleid bepalen.

Voor het bepalen van dat beleid is het van belang daarover onderling optimaal te kunnen communiceren. $\mathrm{Bij}$ die beleidsbepaling ontstaan scholingsbehoeften die onder meer betrekking kunnen hebben op het produceren van processen van doelrealisatie, het organiseren van de besluitvorming, het oplossen van problemen, het toedelen van taken, het zich wederzijds op elkaar betrekken, het leiden en uiteraard het communiceren. Deze scholingsbehoeften gelden ken$\mathrm{nis}$ en vaardigheden die voor elk individu van belang zijn, vervolgens gelden ze voor elke kring, elke kringorganisatie et cetera. Het produceren van de scholing is een taak van de kring en moet ook weer volgens het eerder genoemde patroon worden geschoold en geleerd. 
Het patroon van de leerweg van een kring is weergegeven in figuur 6. De gebruikelijke sociocratische tekenwijze wordt getoond door figuur 7 .

Figurup 6.

Patroon van de leerweg van een kring

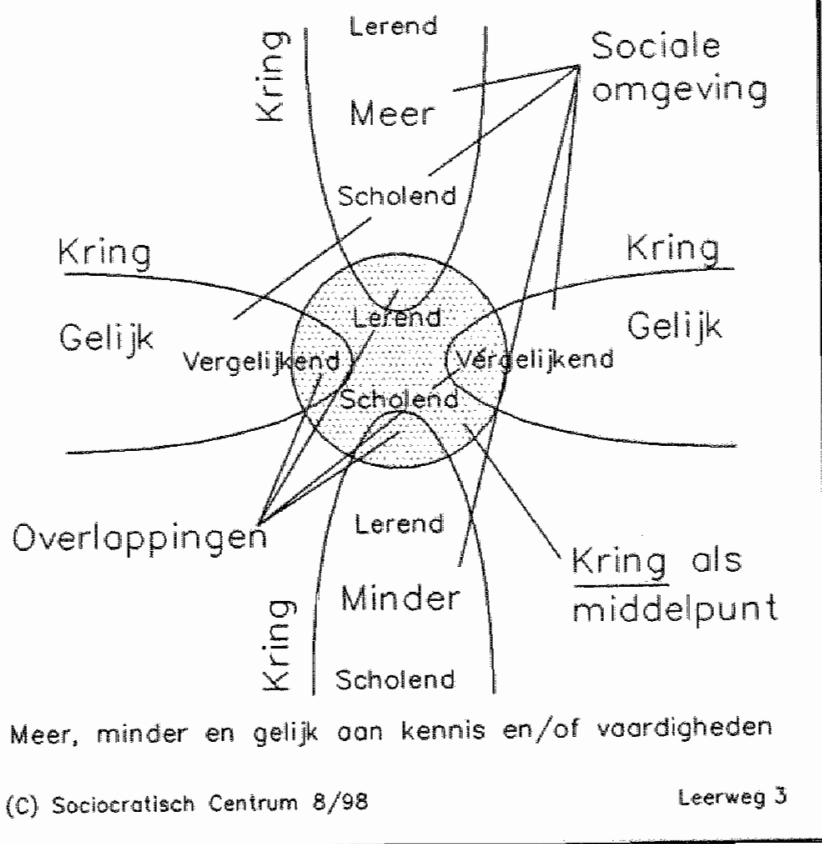




\section{Fïguur 7.}

Beleidsuitvoering en scholingsbehoefien
Leerweg van een kring in de kringorganisatie

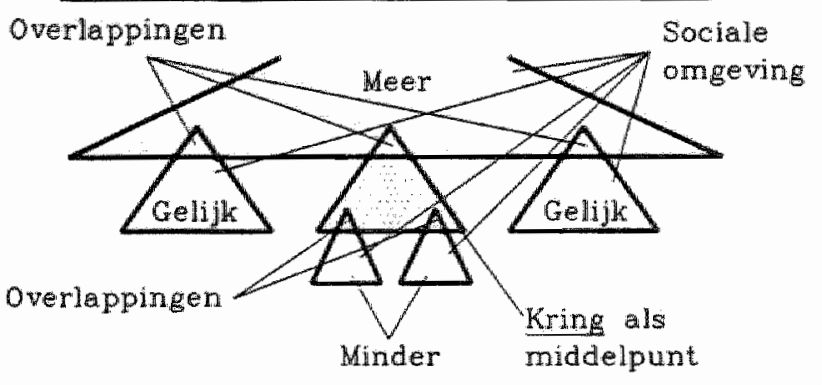

Meer, thinder en gelijk am kennis en/ol vardigheden

(c) Sociocratisch Centrum $7 / 90$

Léregut

De werkorganisatie als plek voor beleidsuitvoering is zodanig gestructureerd dat het proces van doeirealisatie kan ontstaan. De kringleden vervullen dalarin ieder een eigen pakket van functie(s) en taken. De structuur geeft de verbindingen en overlappingen tussen de functies en taken aan. Bij de invulling daarvan ontstaan leerbehoeften. De structuur van de leidinggevende organisatie vormt een afspiegeling van het leerpatroon. De leidinggevende structuur kan dus worden gebruikt voor het eerder besproken individuele leerproces. Zie daarvoor figuur 8. 
Uitoefening wan professie bij proces van doelreolisatie

sociale.

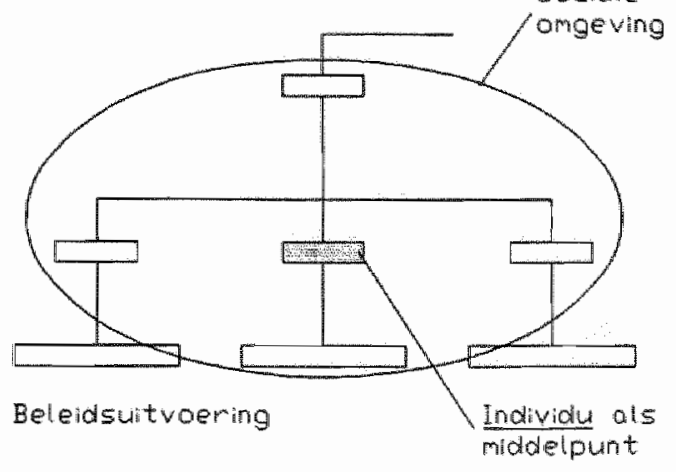

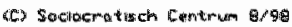

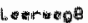

De leerbehoeften die daarbij ontstaan betreffen in hoofdzaak het vak, dat een deelnemer in thet proces van doelrealisatie uitoefent.

Op deze wijze ontstaan er voor ieder individu binnen een kring één of meer formele leerwegen. Die behoren zo 'leeg' te zijn dat zij de impliciete leerwegen faciliteren. De scholing nodig voor de beleidsuitvoering, dat will zeggen, het vak en de scholing nodig voor de beleidsbepaling, dat wil zeggen, de eerder genoemde vijf kennisgebieden en vaardigheden, de 'hardware', vormen met elkaar de 'integrale' scholing zoals bedoeld in de tweede basisregel.

Een opmerkelijke conclusie die volgt wit het beantwoorden van de vormgevingsvragen is, dat elk individu, elke kring, en elke kringorganisatie én of meer eigen, unieke leerweg(en) zal inslaan. 
Afhankelijk van de eigen identiteit, de eigen behoeften aan zingeving en de eigen plek binnen de betrokken structuur ontstaan levenslange, dynamische leerwegen, eindig en onbegrensd. Dit geeft optimale mogelijkheden voor ontwikkeling, maar stelt wel eisen aan de vormgevingskant daarvan. Om bijvoorbeeld het samenwerken mogelijk te maken is de toetsings- of meetvraag nog belangrijker geworden. Hoe geven we die vorm, opdat een zo goed mogelijke afstemming tussen individuen, kringen en kringorganisaties plaatsvindt, levenslang en dynamisch? Wat betekent dit alles voor de vormgeving van scholingsorganisaties, dus ook voor die binnen universiteiten?

Leerweg voor de levende kringorganisatie
Wat in het voorgaande is gezegd over het individu en in analogie daarmee over de kring, geldt ook voor de kringorganisatie als samenstel van kringen. Ook de kringorganisatie heeft een 'zin' of duidelijker: een visie, een missie en een doelstelling. Zij heeft een eigen geheugensysteem als samenstel van die van de kringen. Zij is open, zowel in bestuurlijke als in producerende zin. En de leerwegen kunnen overeenkomstig de beleidsbepalende kringstructuur en beleidsuitvoerende leidinggevende structuur worden geproduceerd. Dat laatste wil zeggen: worden gemaakt, gebruikt en afgebroken, overeenkomstig de hiervoor gegeven definitie van produceren.

Het begrip 'lerende organisatie' verwijst dus nadrukkelijk naar een leerstructuur, naar een structuur die bestaat uit een complex samenstel van leerwegen. Het prettige is dat die structuur in grote lijnen overeenkomt met de structur van doelrealisatie van een organisatie. Eigenlijk is dat niet zo verrassend, omdat de structuur van doelrealisatie de leerbehoeften oproept. Een kring of een kringorganisatie kan bij het produceren van scholing ook externe organisaties be- 
Relateren van scholende en lerende kringorganisaties trekken, waardoor verbindingen kumen ontstant tussen de kringorganisatie en exteme organisaties die bet verzorgen van scholing tot doel hebben.

De lerende organisatie produceert zijn eigen $5 c h 0$ ling en kan daarvoor, zoals hiervoor vermeld, de hulp van een scholingsorganisatie vragen. De vraag is dan op welke wijze die twee organisaties zodanig net elkaar kunnen worden verbonden, dat de onderlinge gelijkwaardigheid bij de besluitvorming kan worden gehandhaafd.

Wanneer aan de bestaande structuur van het onderwijs de sociocratische kringorganisatie word toegevoegd is het mogelijk om relaties net leerstructuren. van andere kringorganisaties aan te gaan, waarby ook voor die relaties de onderlinge gelijkwaardigheid bij de besluitvorming kan blijven gelden. Aldus ontstant een bestuurbare relatie, zodat de scholende organisatie een bestuurbare bijdrage aan de leerbehoeften van gerelateerde kringorganisaties kan leveren.

Figure 9 .

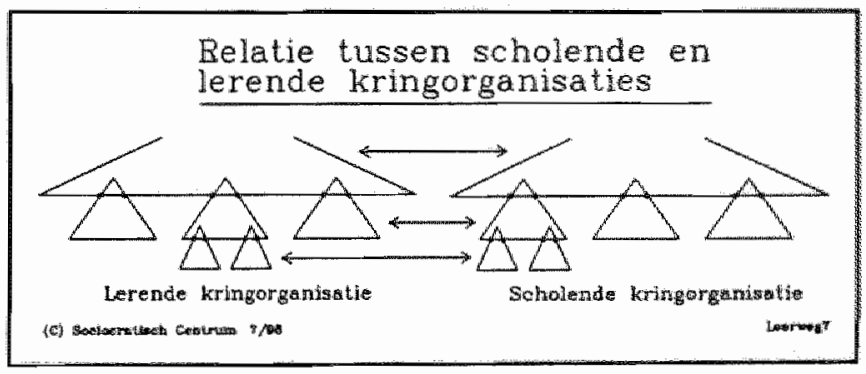

Bijvoorbeeld (zie figuur 9) het relateren van de leerstructuur van onderwijs aan dat van het bedrijfsleven of van een onderwijskringorganisatie aan die van een onderneming. Wanneer de onderlinge gelijkwaardigheid bij de besluitworming van beide kringorganisattes ook geldt voor de relatie tussen die twee is er een sa- 
menwerking ontstaan waarbij gelijkwaardigheid de besluitvorming regeert.

Betekenis

voor

Universiteit

Maastricht
Zoals $u$ zult begrijpen geldt wat ik hiervoor betoogde ook voor het onderwijs zelf, dus ook voor deze universiteit. Een niet te onderschatten voordeel is dat hier al enkele jaren enige ervaring is opgedaan met onderwijsvormen en zogenaamde afstudeerkringen die mede zijn gebaseerd op sociocratische principes. ${ }^{6} \mathrm{Be}-$ moedigend, voor èn de studenten èn de docenten die met elkaar op basis van onderlinge gelijkwaardigheid kunnen werken aan een plezierige en effectieve leerweg. Plezier in het studeren voor studenten en docenten, het verdwijnen van een overmaat aan stress, het beoordelen door wederzijds op elkaar betrokken te zijn, grotere leereffectiviteit, et cetera.

Het succes van dit initiatief stimuleert ook studenten en docenten van andere universiteiten, gezien de verzoeken tot deelname en nadere informatie. Zoals gezegd, ik ben blij met de formulering van de leeropdracht van mijn leerstoel en hoop middels dat wat ik heb uiteengezet een bijdrage aan het succes van deze universiteit te kunnen leveren.

Ik dank u voor uw aandacht en hoop dat we ons wederzijds op deze materie kunnen betrekken ten bate van èn ons zelf èn deze organisatie.

${ }^{6}$ Zle: Romme, A.G.L., Naar samerwwerkend leren in het universitair onderwijs, Tijdschrift voor Hoger Onderwijs, 16 (1998), p. 100-116; Romme, A.G.L., Redistributing power in the classroom, in: J. Troy, M. Pettigrew, P. Keizer \& J. Hommes (eds.), Learning in a changing enwironment, Dordrecht: Kluwer, 1999, forthcoming. 
In de reeks Oraties en Redes zijn onderstaande titels verkrijgbaar bij uw boekhandel of rechtstreeks bij Eburon (Tel.: 015-2131484).

Baden-Fuller, C.

Creating and Maintaining Strategic Innovations

Bahlmann, J.P. Bedrijfseconomie in een Turbulente Wereld.

Berkel, P. van Bedrijfskunde en Rationaliteit Bosch, F.A.J. vd Over de Grenzen van Organisaties Buitendam, A. Prometheus in Arbeidsland Hendrikse, G. $3-1=1$ en meer dan 7 is te veel Janssen, M.C.W.

Over de Grenzen van de Micro-Economie Krug, B. On Mores, Manners and Marginal Utility Leijnse, F. Verzorgingsstaat: Last of Lust? Veerman, C.P. Denkend aan Holland Verhaegen, P.H.A.M. Balanceren tussen Markt en Organisatie 